\title{
DETERMINING PHYSICAL PROPERTIES OF JATROPHA CURCAS L. GRAINS
}

\section{Ednilton Tavares de Andrade}

Federal University of Lavras (UFLA), Agricultural Engineering Dept., CEP 37200-000, Lavras, MG, Brazil

\author{
Renan Pereira Rezende \\ Federal University of Lavras (UFLA), Agricultural Engineering Dept., CEP 37200-000, Lavras, MG, Brazil \\ Corresponding author: renanprezende@gmail.com
}

\section{Jacqueline Maciel Brasil}

Fluminense Federal University (UFF), Agricultural and Environmental Engineering Dept., CEP 24220-900, Niterói, RJ, Brazil

\section{Neila Saraiva Freixo}

Fluminense Federal University (UFF), Agricultural and Environmental Engineering Dept., CEP 24220-900, Niterói, RJ, Brazil

\section{Patrícia Moraes Araújo}

Fluminense Federal University (UFF), Agricultural and Environmental Engineering Dept., CEP 24220-900, Niterói, RJ, Brazil

\begin{abstract}
:
The objective of this study was to determine the physical properties of Jatropha curcas grains, such as: size, shape, density and porosity, and to determine the terminal velocity, comparing the results with those calculated from mathematical models available in the literature. To perform the experimental analysis, samples with different moisture contents, between 4 and $25 \%$ $(\mathrm{wb})$, were selected. To determine the size and shape of the grains, sphericity and roundness characteristics were used, and it was found that both stay approximately constant, despite different moisture content. For specific weight and porosity, results show that the porosity is directly proportional to the moisture content until the point where interaction between the moisture content and volumetric contraction causes the specific weight to increase again, thus decreasing porosity. It was also found that the equation used for calculating the terminal velocity is in agreement with the results obtained experimentally. Furthermore, the results also show that the terminal velocity for the Jatropha grains is directly proportional to its moisture content.
\end{abstract}

Index terms: Oilseed, postharvest, terminal velocity.

Received: August 27, 2018 - Accepted: October 18, 2018.

\section{INTRODUCTION}

For many years, researches on bioenergy have received special attention. Among the main forms of energy obtained from biomass is biodiesel. Besides being clean and renewable, biodiesel also enables a reduction on conventional diesel fuel importation, representing an important opportunity of economic development for many regions (Laviola et al., 2013).

Biodiesel can be extracted from vegetable oil, animal fats and even used frying oil. Jatropha curcas presents itself as a promising culture, with a potential productivity three times larger than that of soybean (Holanda, 2004). One of its main advantages is the long productive cycle, that can reach 40 years and keep an average productivity of 2 ton.ha ${ }^{-1}$ (Melo et al., 2006). The oil content in each Jatropha curcas seed is between 35 to $37 \%$, which is lower than some other oleaginous plants. However, its resistance to normally inadequate conditions for crops, along with its adaptability to desert, saline, marginal and with extreme $\mathrm{pH}$ soils, makes it an ideal plant for 
biodiesel production in otherwise unproductive areas. For being perennial, it also contributes to soil conservation and reduces the production costs, an important factor for its economic feasibility, especially in familiar agriculture. Another advantage is that it allows cultivation amongst other crops of interest (Padilha et al., 2016). Besides, its presence in areas of strong aridity protects the soil from water and wind erosion, and increases air humidity. One hectare can produce 6 to 8 tons of Jatropha curcas seeds, while the same area sown with castor bean produces 3 to 5 tons of seeds. In liters of oil, the Jatropha curcas would produce 2100 to $2800 \mathrm{~L}$ and the castor bean 1200 to $2000 \mathrm{~L}$ per hectare.

The main applications of knowledge of the physical properties of grains relate to the design, construction and operation of equipment for cleaning, drying, classification, storage and industrialization, optimization of equipment operation aiming at higher efficiency, energy savings, pollution control and cost-cutting.

Terminal velocity is determined in order to obtain the maximum speed to be imposed in the air in cleaning equipment, so that grains are not transported with impurities (Teixeira et al., 2003). This property is also used on pneumatic transporting, densimetric selection, cooling, among others (Mohsenin, 1986).

Therefore, this paper' sobjective is to determine the main physical characteristics of Jatropha grains, such as size, shape, specific weight and porosity, and to experimentally determine the terminal velocity of the air involved in the postharvest processes, making a comparison between the experimental results obtained and those calculated using mathematical models.

\section{MATERIAL AND METHODS}

This study was conducted in the Agricultural and Environment Engineering Department and in the Thermosciences Laboratory (Latermo) on the Fluminense Federal University (UFF), Niterói, RJ. Jatropha curcas L. grains, with initial moisture content of $25 \%(\mathrm{wb})$, manually harvested from the municipal garden of Macaé, RJ, were used.

The initial sample was divided into subsamples of approximately $250 \mathrm{~g}$. The first was kept in an airtight bag, in order to preserve its original moisture content. The other subsamples were dried to moisture contents of approximately 4,8 , $9,11,13,15,18,20,24$ and 25\% (wb). After drying the grains were homogenized, stored in airtight bags and put in refrigeration. Posteriorly the moisture content of each sample was determined.

\section{Moisture content}

In order to determine the moisture content of the grains, were realized according to the recommendations of (Brasil, 1992), as it is shown in Equation 1:

$$
\mathrm{U}=\left(\mathrm{P}_{i}-\mathrm{P}_{f}\right) \cdot\left(\mathrm{P}_{i}\right)^{-1} \cdot 100
$$

where:

$\mathrm{U}$ : moisture content $(\% \mathrm{wb})$;

Pi: initial weight of sample $(\mathrm{g})$;

Pf: final weight of sample (g).

For each treatment, 3 samples of approximately 30 grams were used. These were housed at $105 \pm 1$ ${ }^{\circ} \mathrm{C}$ for a period of 24 hours. After this time, the samples were placed in a desiccator, until ambient temperature was reached for weighting. The difference on initial and final mass represents the mass of water contained in the grains.

\section{Size and shape}

For the determination of size and shape, samples of 200 grains were used for each moisture content. The grain size was determined using a digital caliper, measuring the width, length and thickness of each grain, as shown in illustration of grain dimensions (Figure 1).

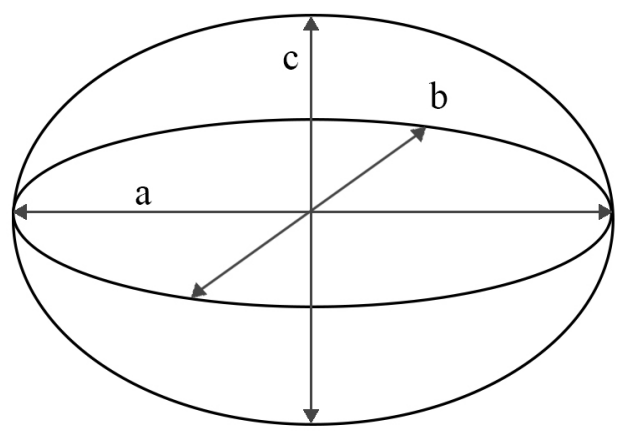

Figure 1: Grain dimensions: Width (a), Thickness (b) and Length (c). 
The shape was characterized by calculating the gran circularity and sphericity. Circularity is the measure of how closely the shape of an object approaches that of a mathematically perfect circle. It can be expressed as the ratio of the largest projected area of the object in natural resting position to the area of the smallest circumscribed circle. For the delimitation of the circumscribed and inscribed circles, and the projected area, AutoCad 2008 was used by inserting an image taken from the grain and then delineating the grain and the circles (Figure 2).

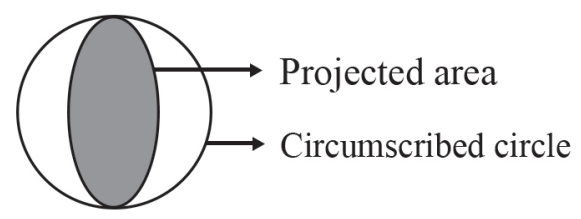

Figure 2: Projected area and circumscribed circle.

\section{Specific weight}

The specific weight was determined with 7 repetitions for each sample, using a $1000 \mathrm{~mL}$ beaker and a precision scale.

After the scale is balanced with the ambient, the dry beaker is weighted, becoming the curb weight. The grains were deposited in the beaker to the $1000 \mathrm{~mL}$ mark and then weighted. The specific weight was then obtained using Equation 2.

$$
\gamma=\mathrm{m} \cdot \mathrm{V}^{-1}
$$

where:

$\gamma$ : specific weight $\left(\mathrm{kg} . \mathrm{m}^{-3}\right)$;

$\mathrm{m}$ : mass (kg);

$\mathrm{V}$ : volume $\left(\mathrm{m}^{3}\right)$.

\section{Porosity}

Porosity was determined by the direct method, where it is obtained by adding a known liquid in order to complete the spaces of the granular mass (Mohsenin, 1986). Beakers of $500 \mathrm{~mL}$ and $100 \mathrm{~mL}$ were used, with soybean oil being the chosen liquid.

\section{Experimental terminal velocity}

The terminal velocity was determined by using a device made of a fan coupled to a PVC tube with diameter of $100 \mathrm{~mm}$ and $1040 \mathrm{~mm}$ in length. These dimensions were used in order to obtain a greater uniformity of air distribution in the cross section of the tube, in accordance to Mohsenin (1986). At a distance of $7.5 \mathrm{~cm}$ from its upper end, a net was attached to sustain the samples. At the fan inlet, at a distance of $70 \mathrm{~cm}$, a gate valve was used to control the air flow. The air velocity was measured $7.5 \mathrm{~cm}$ above the sustaining net, using a digital anemometer. The measurement of the air velocity (which corresponds to the terminal velocity) was performed at the beginning of sample trepidation, to avoid its fluctuation. Figure 3 shows the schematic of the equipment used.

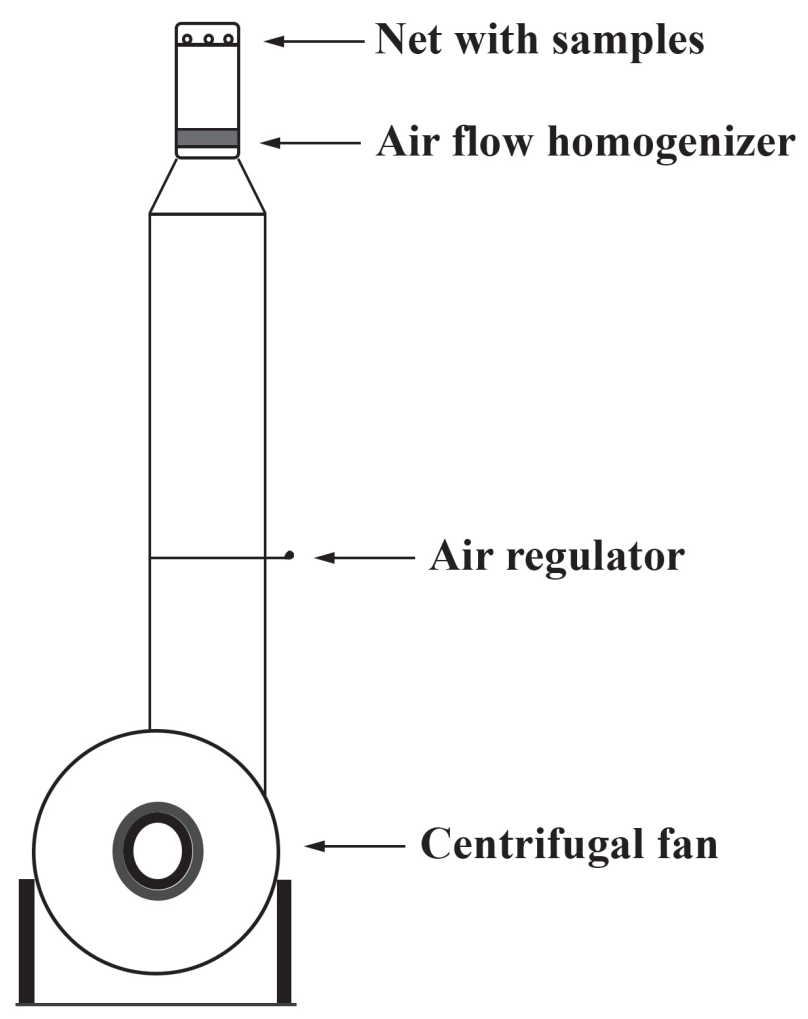

Figure 3: Schematic of the equipment used for measuring the terminal velocity.

The terminal velocity was obtained for 7 samples with different moisture contents. For each sample, 7 grains weighting between 0.7 and 1.0 grams were used. 


\section{Calculated terminal velocity}

The terminal velocity was calculated for comparison between the experimental results with results obtained from mathematical models. The Equation 3 proposed by Hawk et al. (1966) was used.

$\mathrm{V}_{\mathrm{t}}=\left[\frac{2 \cdot \mathrm{w} \cdot(\mathrm{pp}-\mathrm{pf})}{\mathrm{C} \cdot \mathrm{pp} \cdot \mathrm{pf} \cdot \mathrm{Ap}}\right]^{\frac{1}{2}}$

where,

$\mathrm{Vt}=$ terminal velocity $\left(\mathrm{m} \cdot \mathrm{s}^{-1}\right)$;

$\mathrm{w}=$ weight of the particles $(\mathrm{N})$;

$\rho p=$ specific weight of the particles $\left(\mathrm{kg} \cdot \mathrm{m}^{-3}\right)$;

$\rho \mathrm{t}=$ specific weight of the fluid $\left(\mathrm{kg} \cdot \mathrm{m}^{-3}\right)$;

$\mathrm{C}=$ drag coefficient, dimensionless;

$\mathrm{Ap}=$ projected area of the particles, normal to its movement in relation to the fluid $\left(\mathrm{m}^{2}\right)$;

$\mathrm{G}=$ gravity acceleration $\left(\mathrm{m} \cdot \mathrm{s}^{-2}\right)$.

\section{RESULTS AND DISCUSSION}

Table 1 presents the average values for width (a), length (c) and thickness (b), and the moisture content of each sample. It is noted an increase of those values as the moisture content increases. Thickness show less variation, which was expected, as it is the smaller axis.

Table 1: Average values for width, length and thickness, for each moisture content.

\begin{tabular}{cccc}
\hline $\begin{array}{c}\text { Moisture } \\
\text { content }(\% \mathrm{wb})\end{array}$ & $\begin{array}{c}\text { Width (a) } \\
(\mathrm{mm})\end{array}$ & $\begin{array}{c}\text { Length (c) } \\
(\mathrm{mm})\end{array}$ & $\begin{array}{c}\text { Thickness } \\
(\mathrm{b})(\mathrm{mm})\end{array}$ \\
\hline 4.3 & 10.965 & 17.275 & 8.400 \\
8.3 & 11.205 & 17.555 & 8.825 \\
13.3 & 11.215 & 17.520 & 8.790 \\
17.8 & 11.238 & 17.570 & 8.870 \\
23.7 & 11.358 & 17.793 & 9.003 \\
\hline
\end{tabular}

On Table 2, the average values for circularity and sphericity of grains for each moisture content are shown. Both circularity and sphericity values remained approximately constant, despite different values of moisture content. As expected, the weight increased with higher moisture contents.
Table 2: Average values for circularity, sphericity and weight of 1000 grains, for each moisture content.

\begin{tabular}{cccc}
\hline $\begin{array}{c}\text { Moisture } \\
\text { content }(\% \mathrm{wb})\end{array}$ & Circularity & Sphericity & $\begin{array}{c}\text { Weight of } 1000 \\
\text { grains }(\mathrm{kg})\end{array}$ \\
\hline 4.3 & 0.598 & 0.570 & 0.777 \\
8.3 & 0.595 & 0.575 & 0.794 \\
13.3 & 0.582 & 0.565 & 0.825 \\
17.8 & 0.602 & 0.571 & 0.889 \\
23.7 & 0.604 & 0.576 & 0.954 \\
\hline
\end{tabular}

The average values for specific weight and porosity are presented on Table 3. Porosity is directly proportional and specific weight is indirectly proportional to the moisture content up to a certain point (around 14\% of moisture content). At this point, the interaction between moisture content and volumetric contraction causes the specific weight to increase again, thus decreasing porosity. This can be explained due to the fact that moisture content has influence on the volume contraction of the grain, making its volume vary.

Table 3: Average values for specific weight and porosity, for each moisture content.

\begin{tabular}{ccc}
\hline $\begin{array}{c}\text { Moisture content } \\
(\% \mathrm{wb})\end{array}$ & $\begin{array}{c}\text { Specific weight } \\
\left(\mathrm{kg} \cdot \mathrm{m}^{-3}\right)\end{array}$ & $\begin{array}{c}\text { Porosity } \\
(\%)\end{array}$ \\
\hline 4.3 & 480.47 & 44.93 \\
8.3 & 436.66 & 47.00 \\
13.3 & 430.40 & 47.08 \\
17.8 & 439.34 & 46.42 \\
23.7 & 446.72 & 45.56
\end{tabular}

The values for specific weight were adjusted in a cubic function. The obtained adjusted function has an $\mathrm{R}^{2}$ value of 0.997 , and is represented by Equation 4.

Specific weight calculated $=-0.0388 \cdot \theta^{3}+$

$1.9833 \cdot \theta^{2}-30.805 \cdot \theta+579.0$

where $\theta=$ moisture content $(\% \mathrm{wb})$.

The experimental and calculated values of specific weight, for each moisture content are presented on Table 4 . The simulated values for 
the specific weight of the grains adequately represented the variation of this property with the moisture content.

Likewise, porosity can be calculated through the adjusted equation (with $\mathrm{R}^{2}=0.995$ ), shown in Equation 5:

Specific weight calculated $=-0.0388 \cdot \theta^{3}+$

$1.9833 \cdot \theta^{2}-30.805 \cdot \theta+579.0$

where $\theta=$ moisture content $(\% \mathrm{wb})$.

The experimental and calculated porosity, for each moisture content are presented on
Table 5. The simulated values for the porosity of the grains adequately represented the variation of this property with the moisture content.

Figure 4 below shows the values for experimental and calculated porosity and specific weight as moisture content increases.

On Table 6, obtained values of experimental and calculated terminal velocity for each sample are presented. It was found that terminal velocity is directly proportional to the moisture content. This increase is possibly due to the physical changes on the grain, mostly its weight, area and volume, as moisture content changes.

Table 4: Experimental and calculated values of specific weight, for each moisture content.

\begin{tabular}{ccc}
\hline Moisture content $(\% \mathrm{wb})$ & Experimental $\left(\mathrm{kg} \cdot \mathrm{m}^{-3}\right)$ & Calculated $\left(\mathrm{kg} \cdot \mathrm{m}^{-3}\right)$ \\
\hline 4.3 & 480.47 & 479.93 \\
8.3 & 436.66 & 438.30 \\
13.3 & 430.40 & 428.32 \\
17.8 & 439.34 & 440.40 \\
23.7 & 446.72 & 455.51 \\
\hline
\end{tabular}

Table 5: Experimental and calculated porosity.

\begin{tabular}{ccc}
\hline Moisture content $(\% \mathrm{wb})$ & Experimental $(\%)$ & Calculated $(\%)$ \\
\hline 4.3 & 44.93 & 44.95 \\
8.3 & 47.00 & 46.91 \\
13.3 & 47.08 & 47.21 \\
17.8 & 46.42 & 46.34 \\
23.7 & 45.55 & 45.01 \\
\hline
\end{tabular}

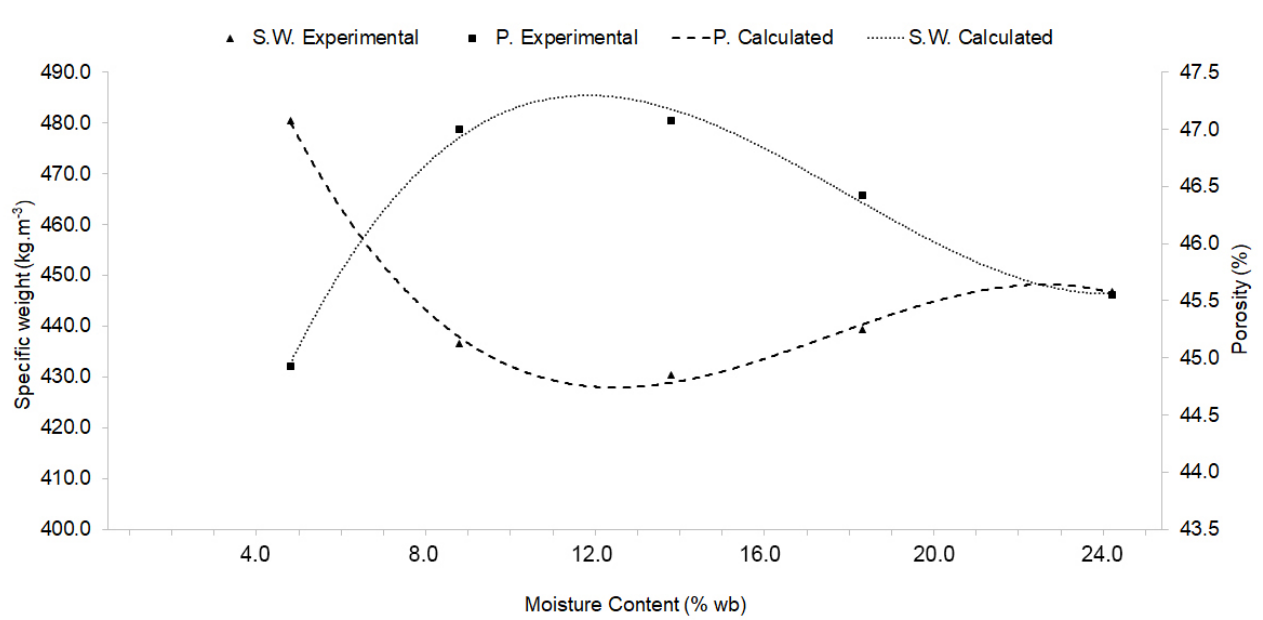

Figure 4: Values for porosity (\%): experimental (P. Experimental) and calculated (P. Calculated), and values for specific weight $\left(\mathrm{kg} . \mathrm{m}^{-3}\right)$ : experimental (S.W. Experimental) and calculated (S.W. Calculated), for each moisture content (\% wb). 
Table 6: Obtained results for experimental and calculated Terminal Velocity $\left(\mathrm{m} \cdot \mathrm{s}^{-1}\right)$, for each moisture content.

\begin{tabular}{ccc}
\hline Moisture content $(\% \mathrm{wb})$ & Experimental $\left(\mathrm{m} . \mathrm{s}^{-1}\right)$ & Calculated $\left(\mathrm{m} . \mathrm{s}^{-1}\right)$ \\
\hline 3.9 & 7.81 & 7.79 \\
8.8 & 7.96 & 7.95 \\
10.8 & 8.09 & 8.03 \\
14.7 & 8.29 & 8.20 \\
16.7 & 8.43 & 8.30 \\
18.9 & 8.67 & 8.42 \\
25.0 & 8.97 & 8.81 \\
\hline
\end{tabular}

\section{CONCLUSIONS}

Jatropha grain's width, length and thickness increase as its moisture content increases. Circularity and sphericity remain approximately constant, despite different values of moisture content. Porosity increases with the moisture content, but only to up a certain point. Around $14 \%$ moisture content, the interaction between moisture content and volumetric contraction causes the specific weight to increase instead of decrease, thus decreasing porosity.

For terminal velocity, the experimental values are in accordance to the ones obtained by using mathematical models. The results also show that terminal velocity is directly proportional to the moisture content of the grain.

The methodology used in this work was adequate to determine the physical properties of Jatropha curcas.

\section{REFERENCES}

ALVES, R. S. et al. Selection of Jatropha curcas families based on temporal stability and adaptability of genetic values. Industrial Crops and Products, 119:290-293, 2018.

BRASIL. Regra para análise de sementes. Ministério da Agricultura e Reforma Agrária. Brasília, DF: MARA, 1992. 365p.

DÍAZ-LÓPEZ, L. et al. Jatropha curcas seedlings show a water conservation strategy under drought conditions based on decreasing leaf growth and stomatal conductance. Agricultural Water Management, 105:48-56, 2012.

HAWK, A. L.; BROKER, D. B.; CASSIDY J. J. Aerodynamic characteristics of selected farm grains. Transactions of the ASAE, 9(1):48-51, 1966.

HOLANDA, A. Biodiesel e inclusão social. Brasília : Câmara dos Deputados, Coordenação de Publicações, 2004. 200 p.

LAVIOLA, B. G.; ALVES, A. A.; ROCHA, R. B. The importance of Jatropha for Brazil, Jatropha, challenges for a new energy crop. Farming, economics and biofuel. New York: Springer, 2013. v. 1.

MELO, A. et al. Avaliação preliminar do potencial do pinhão-manso para a produção de biodiesel, I Congresso da Rede Brasileira de Tecnologia de Biodiesel, 2006, p.1-3.

MOHSENIN, N. N. Physical properties of plant and animal materials. New York: Gordon and Breach Publishers, 1986, 841p.

PADILHA, N. S.; SILVA, C. J.; PEREIRA, S. B. Crescimento inicial do pinhão-manso submetido a diferentes regimes hídricos em latossolo vermelho distrófico. Ciência Florestal, 26(2):513-521, 2016.

TEIXEIRA, M. M.; PETER, J. M; HARA, T.; CUNHA, J. P. A. R. Propriedades físicas e aerodinâmicas aplicadas ao projeto de máquinas de e limpeza para grãos de milho. Engenharia na Agricultura, 11:54-55, 2003.

WEST, N. L. Aerodynamic force predictions. St. Joseph, Michigan: ASAE, 1970. 4p. 